\title{
Soaking in Cold Water Replaces the Stratification Requirement of True Cedar Seeds
}

\author{
David Brand \\ Forest Resources, Forest Department, Land Development Authority, P.O. Box \\ 45, Kiryat-Haim 26103, Israel \\ Joseph Riov \\ Department of Horticulture, Faculty of Agriculture, The Hebrew University of \\ Jerusalem, P.O. Box 12, Rehovot 76100, Israel
}

Additional index words. Cedrus deodara, uniform emergence, dormancy

There is an increasing demand from growers for seeds to be of the highest vigor possible, with the ability to emerge rapidly, uniformly, and to a high level. Seed priming (soaking in salt, osmoticum, or water solutions) can accelerate germination and seedling establishment. This technique is a well-established practice for some horticultural crops (Parera and Cantliffe, 1994) and forest trees (Struve et al., 1991). True cedars (Cedrus sp.) are common forest trees in the Mediterranean basin and are also widely used as ornamental trees in Europe, the United States, and other countries. Seeds of true cedars usually require stratification for 2 weeks to improve germination (Heit, 1968). Since the stratification period must be accompanied by adequate water uptake (Bonner et al., 1989), we examined whether soaking true cedar seeds in cold water could reduce or replace their stratification requirement.

Fresh seeds (one lot) of Cedrus deodara (D. Don.) were obtained from Setropa Ltd., Bussum, The Netherlands. Seeds were stored dry at $4{ }^{\circ} \mathrm{C}$ and used for the experiments within 4 months after collection. Seeds were soaked in aerated water solutions in 9-L polystyrene containers; an airstone placed on the bottom of the containers supplied air at a rate of 1.5 $\mathrm{L} \cdot \mathrm{min}^{-1}$. The rate of airflow was controlled by flowmeters. One hundred seeds were placed in a net bag floating in the water and were soaked in the dark for $2 \mathrm{~d}$ at 4 or $19^{\circ} \mathrm{C}$. Additional seeds were stratified in moist vermiculite at $4{ }^{\circ} \mathrm{C}$ for 2 weeks. To determine emergence, seeds were sown in vermiculite in germination trays placed in a growth chamber under the following con-

Received for publication 25 Aug. 1998. Accepted for publication $5 \mathrm{Feb}$. 1999. The cost of publishing this paper was defrayed in part by the payment of page charges. Under postal regulations, this paper therefore must be hereby marked advertisement solely to indicate this fact. ditions: $16 \mathrm{~h}$ light $\left(130 \mu \mathrm{mol} \cdot \mathrm{m}^{-2} \cdot \mathrm{s}^{-1}\right.$ at the surface of the medium) and temperature of 22 ${ }^{\circ} \mathrm{C}$ light $/ 18^{\circ} \mathrm{C}$ dark.

Soaking seeds in water at $4{ }^{\circ} \mathrm{C}$ for $2 \mathrm{~d}$ accelerated seedling emergence and somewhat increased the final percent emergence as compared with stratification (Fig. 1). Of particular interest is the more uniform emergence obtained by cold soaking; maximum emergence was obtained after $19 \mathrm{~d}$, whereas emergence of seedlings from stratified seeds in creased gradually during the entire experimental period ( $28 \mathrm{~d}$ ). The response to cold soaking probably reflected the combined effects of low temperature and uptake of water, as soaking was much more effective at $4{ }^{\circ} \mathrm{C}$ than at $19^{\circ} \mathrm{C}$. Aeration of the treatment solutions was essential, since without aeration emergence was low (data not presented).

The data show that soaking $C$. deodara seeds in aerated water at low temperature mainly improved the uniformity of seedling emergence. Uniform emergence is necessary to reduce the period of susceptibility to certain diseases, improve crop uniformity, and increase seedling size. Cold soaking increased the final emergence percentage only slightly above that of stratified seeds. However, this effect was consistent in all the experiments performed (Fig. 1 and two additional experiments not presented), and may also be beneficial due to the low germination rates $(\approx 50 \%)$ of true cedars, primarily because of low viability (Bonner et al., 1989). Cold soaking also stimulates germination of $C$. atlantica seeds (Siaki, 1999). Results in this and previous studies suggest that cold soaking can replace stratification completely in seeds that require a short period of stratification, but only partly in seeds with longer stratification periods (Janerette, 1979).

\section{Literature Cited}

Bonner, F.T., B.F. McLemore, and J.P. Barnett. 1989. Presowing treatment of seed to speed germination, p. 126-135. In: Seed of woody plants in the United States. U.S. Dept. Agr., For. Serv. Agr. Hdbk. No. 450, Washington, D.C.

Heit, C. 1968. Propagation from seed. Part 16: Testing and growing Cedrus species. Amer. Nurseryman 128:12-13, 87-94.

Janerette. C.A. 1979. Cold soaking reduces the stratification requirement of sugar maple seeds. Tree Planters' Notes 30:3-4.

Parera, C.A. and D.J. Cantliffe. 1994. Presowing seed priming. Hort. Rev. 16:109-139.

Siaki, G. 1999. Improvement of nursery methods for difficult-to-grow forest tree species. MSc Thesis, The Hebrew Univ. of Jerusalem, Israel (in Hebrew with English summary).

Struve, D.K., M.F. Dress, and M.A. Bennett. 1991. Aerated water soak increases red oak seed germination and seedling emergence. Can. J. For. Res. 21:1257-1261.

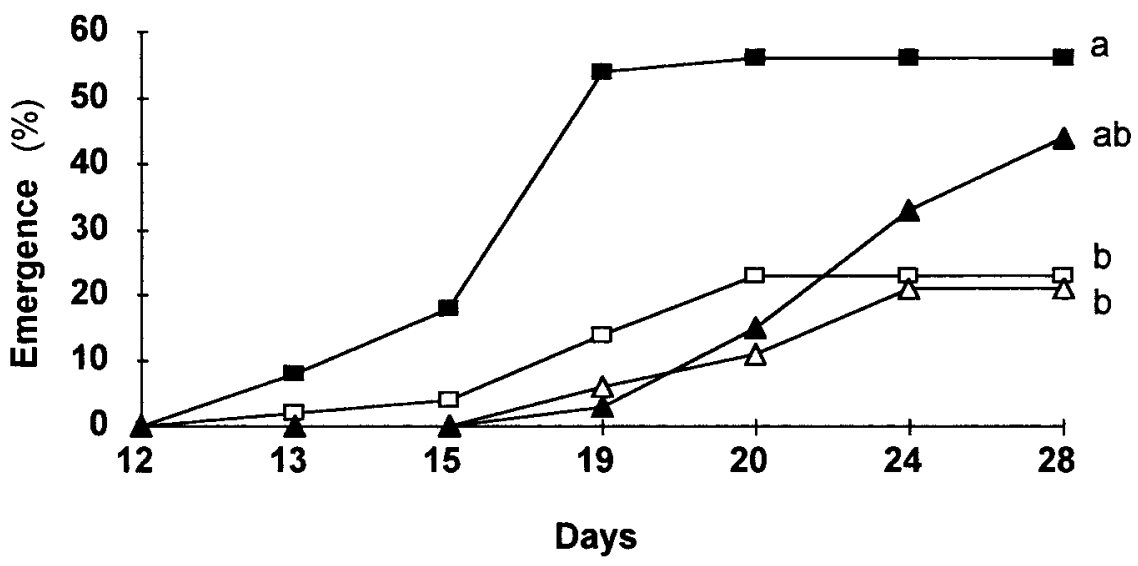

Fig. 1. The effect of seed pretreatment on the emergence of $C$. deodara seeds. The pretreatments were: aerated solution for $2 \mathrm{~d}$ at $4{ }^{\circ} \mathrm{C}(\boldsymbol{\square})$, aerated solution for $2 \mathrm{~d}$ at $19{ }^{\circ} \mathrm{C}(\square)$, stratification for $14 \mathrm{~d}$ at $2{ }^{\circ} \mathrm{C}$ $(\boldsymbol{\Delta})$, no pretreatment $(\Delta)$. Mean separation by chi square at $P \leq 0.05$ is presented for the final emergence percentage. 